\title{
Private Financing and Human Resource Practices of Small Local and Foreign-Owned Cosmetological
} Businesses

\author{
Patient Rambe \\ Central University of Technology, Bloemfontein, South Africa \\ prambe@cut.ac.za
}

\begin{abstract}
There exists a growing body of empirical studies that explore both the sources of small, micro and medium enterprises (SMME) funding, and the quality of their human resource practices. However, there is paucity of literature that interrogates the impact of private funding of local and foreign SMMEs on the quality of human resources. Nevertheless, the wide recognition of the economic significance of SMMEs in emerging economies and the pivotal role that funding plays in the growth of such firms suggest that the nexus between SMME private funding and human resourcing is integral to this condition and growth. As a result, the current study examined the influence of private financing of local and foreign-owned hair salon SMMEs on the quality of their human resources, in an attempt to bridge the aforementioned research gap. The study, which drew on a quantitative approach, is based on a survey conducted on 150 South African and foreign immigrant-owned hair salon businesses. The findings suggest that the private financing structure was dominated by a combination of debt and equity financing, followed by debt financing, with equity financing as the least employed funding model. The study established the significant impact that access to private equity financing has on recruitment, selection and compensation. However, the level of private debt financing, attractiveness of interest rates for private debt financing and financial value of funding from private institutions (banks) do not have any impact on human resources management practices. A major observation from the results is that, some aspects of private financing impact negatively on human resources management albeit a small effect size, which somehow raises critical questions about the popular claims that financing, contributes positively to the quality of human resources of firms.
\end{abstract}

Keywords: Hair salons, private financing, small foreign owned businesses, private equity

\section{Introduction}

The reality that small, cosmetological South African businesses, such as hair salons, tend to be predominantly female managed and foreign immigrant-owned entities, makes them susceptible to financial exclusion as they may not qualify for funding options availed by national and private funding institutions. Both local and foreign immigrant female-owned small, micro and medium enterprises (SMMEs) encounter gender discrimination when seeking finance from traditional South African financial institutions and state-owned institutions (Small Enterprise Development Agency, n.d.; United National Development Programme, 2014). The United National Development Programme (2014) bemoans that South African women entrepreneurs still encounter difficulties in accessing finance despite the existence of various financial institutions and funding mechanisms that specifically target women-owned businesses. The foreign and female-owned SMMEs encounter challenges such as poor access to financial assistance, credit and lack of collateral. In addition, their business activities tend to fall predominantly in the informal sector, where engagement in value-adding activities, prospects of business growth, and transition to the mainstream economy is severely limited (Small Enterprise Development Agency, n.d.).

In addition to the literature focusing on meagre financial resources availed to SMMEs, there exists a further stream of research that focuses on the nature of SMMEs' human resource practices (Kim \& Gao, 2010; Lee, Lee \& Wu, 2010; Laforet, 2013; Mpiti, 2016; Nyamubarwa, 2016). The predominantly informal, intuitive, ad hoc and unsophisticated nature of human resource practices of SMMEs (Rand \& Torm, 2012; Sheehan, 2013; Mpiti, 2016; Nyamubarwa, 2016) is attributed to the lack of financial resources to sponsor the establishment and operation of complicated human resourcing processes (Mpiti, 2016; Rambe \& Mpiti, 2017). The largely informal human resource management (HRM) practices of SMMEs are normally in sync with the efficient management of their impoverished resource base and afford them increased flexibility to respond to the ever-changing, complex business environments they operate in (Kim \& Gao, 2010). Conversely, the lack of formal, written HR policies often contributes to high employee absenteeism, turnover, and low employee motivation (Laforet, 2013; Nyamubarwa, 2016). Therefore, one of the critical and yet underestimated 
requirements for SMME success is the presence of a supportive human-resource base, as it fosters an ideal environment within which latent human potentialities are realised (Falkena et al., 2001). As such, formalised HRM practices are desirable as they impact positively on the business strategy and leverage a firm's performance (Lee, Lee \& Wu, 2010; Nyamubarwa, 2016). Nonetheless, the SMMEs' more sophisticated HR practices require stable and consistent private funding, which is highly dependent on the sophistication of financial markets, the regulatory environment within which financial institutions operate and their ability to assess, manage and price the risks associated with loan products for SMMEs (Falkena et al., 2001).

A gap exists between literature that examines the financing of SMMEs on the one hand (Falkena et al., 2001; Fatoki, 2014; Mpiti, 2016) and the formalisation of human resource practices of SMMEs on the other (Cameron \& Miller, 2008; Umer, 2012; Sheehan, 2013; Nyamubarwa, 2016). In addition, there is a paucity of literature that explores the intersection between private financing and human resource practices of SMMEs in emerging economies. Hence, this research explores the impact of private funding on the human resourcing of hair salon SMMEs. While Severino (2012) attempts to bridge the research chasm between SMME private financing and SMME human resource practices by arguing that the profitability of equity or quasi-equity investments in African SMMEs has been compromised by the low levels of human resources and scarcity of local capital, the study adopts a continental perspective rather than a micro perspective adopted in this study. The other complicated dimension is that many entrepreneurs incubate their small businesses with very limited capital and that financial capital is not significantly related to the probability of being a nascent entrepreneur (Davidson \& Honing, 2003; Hurst \& Lursadi, 2004; Simpeh, 2011). As such, the way in which the private financing of SMMEs relate to the quality of human resourcing of such SMMEs remains speculative. The ambiguity of this relationship is further compounded by the reality that most South African SMMEs, including hair salons, operate as low-productivity self-employment or "survivalist" entities for poor households (Davies \& Thurlow, 2009; Demacon Market Studies, 2010), which undermines their capacity to develop formalised human resource practices. The current study, therefore, breaches the knowledge gap between the private funding-human resources relationship by examining the influence of private funding on the quality of SMMEs' human resources within the context of an emerging economy.

The study addresses three research questions and these are:

- What is the composition of the private funding in hair salon SMMEs operating in the Mangaung Metropolitan Area (MMA) of the Free State Province in South Africa?

- Which human resource practices are prevalent among these SMMEs operating in MMA in the Free State Province?

- How is the impact of private funding on the quality of human resources of Afro hair salons in the MMA constituted?

The rest of the paper is structured as follows: the research background and problem statement are outlined, followed by a brief literature review, research methodology, findings and discussion, study implications and the final section focuses on the conclusion to the study.

Problem background: The gulf between the SMME financing literature (Falkena et al., 2001; International Finance Corporation 2011; Mahembe, 2011; Timm, 2012, Fatoki, 2014) and SMME human resourcing (Horwitz, 2013; Almeida et al., 2015; Davis \& Luiz, 2015; Nyamubarwa, 2016) stems from the varied foci of these discourses. The literature on SMME financing has foregrounded: SMMEs' limited awareness of external funding opportunities, nascence of the African financial systems and high cost of borrowing (Beck et al., 2009); SMMEs' bureaucracy which complicates their capacity to capitalise on available funding opportunities (Lekhanya \& Mason, 2014), the complexities in meeting loaning requirements (Chimucheka \& Mandipaka, 2015) and limited access to financing opportunities (Schmidt, Mason, Bruwer \& Aspeling, 2016). This foci on funding can be contrasted with the research on SMME human resourcing that is pre-occupied with the significance and challenge of the adoption of human resources in SMME development (Hung, Cant \& Wiid, 2016); the low human resource and technological capabilities of SMMEs (Hussain, Si \& Wang, 2010), and the influence of human resource management (HRM) practices on SMMEs' financial and non-financial performance (Din, Bibi, Karim \& Bano, 2014). Tiwari and Saxena (2012) acknowledge that the implementation of HRM practices affects employees' attitude, employee-employer relations, employee productivity and the financial performance of the firm. However, the body of literature seems to ignore the 
significance of financing on the operationalisation of HRM practices. As a result, financial matters are mentioned as performance outcomes of good human resource practices (Din, Bibi, Karim \& Bano, 2014), just as the contribution of public and private partnerships (including financial partnerships) in accelerating SMME development and productivity is foreground (Hussain, Si \& Wang, 2010) at the expense of HRM practices.

There are a number of factors that explain the SMMEs' limited pre-occupation with the quality of human resources. These include the size of SMMEs and limited funding, which collectively undermine the development of full-fledged human resource departments and culminates in the fusion of managerial and administrative roles in an individual owner/manager. The Infrastructure Dialogues Report (2015) highlights that the vibrancy, energy and entrepreneurship exhibited in the township economies, where most hair salons and their customers are mostly situated, is nevertheless characterised by the SMMEs' co-existence with poverty, poor facilities and financial investments, and a state of fragmentation among these SMMEs. The characteristic smallness of the SMMEs also deters them from instituting sophisticated human resource systems and hence, their reliance on informal or quasi-formal human resource practices. Critics such as Umer (2012), Blackburn, Hart and Wainwright (2013) and Nyamubarwa (2016) identify informal relationships as one of the key defining characteristics evident in the way SMMEs conduct their business and HR practices. Therefore, resource constraints compel SMMEs to employ limited HR professionals in as much as these businesses encounter difficulties in recruiting and retaining employees, hence their reluctance to engage in costly or restrictive practices (Cardon \& Stevens, 2004; Bhatti et al., 2012).

Large corporation focus: The issue of the quality of SMME human resourcing is often ignored due to literature's pre-occupation with large multinational corporations and their subsidiaries (see Aytaç, Mousseau \& Örsün, 2014; Horwitz, 2015) or with the HRM practices of developed countries (Almeida, Fernando, Hannif \& Dharmage, 2015). Mainstream human resource literature takes little account of the SMMEs' conditions, a situation reflected in an acute shortage of research on HR practices in SMMEs (Richbell, Szerb \& Vitai, 2010, Nyamubarwa, 2016). Nonetheless, an avalanche of employee-related problems and the increasing dissatisfaction of employees with the work place experience (Barrett, 2004) demonstrates the need for [small] organisations to create new human resource systems that deal effectively with changes taking place both internally and externally (van der Walt \& Swanepoel, 2015). The reality that recruitment, selection, compensation, employee relations, performance appraisal, training and development challenges are not unique to large corporations implies that SMMEs are not immune to these challenges as well, considering that SMMEs often lack of coping mechanisms and rely on the authoritative leadership of their owner/managers. The Human Resource Development Strategy for South Africa (HRD-SA) 2010 - 2030 recognises the growing complexity of the work place, how it is being accelerated by the dynamic impact of globalisation on national economies, production and trade, and has placed HRD at the heart of contemporary development strategies.

Problem statement: The gulf between literature that explores the private funding opportunities of SMMEs in emerging economies on the one hand (Falkena et al., 2001; Mahembe, 2011; Timm, 2012; Fatoki, 2014) and SMME HRM practices on the other (Kim \& Gao, 2010; Laforet, 2013; Nyamubarwa, 2016) complicates the understanding of the impact of private financing on human resourcing of SMMEs. Despite the postulated positive relationship between finance and the performance of SMMEs (Zhenxing \& Zheng, 2008; OECD, 2015), there is limited literature that explores the influence of private finance on the human resourcing of SMMEs (Mpiti, 2016; Rambe \& Mpiti, 2017). Yet well managed and sufficiently resourced human resources are one of the most strategic factors that provide flexibility and adaptability to organizations (Khatri, 1999; Tiwari \& Saxena, 2012). This limited focus on the financing-HR relationship within SMME context could be attributed to the absence of formal HR departments in most SMMEs (Aldrich \& Von Glinow, 1991), the difficulty of recruiting and retaining employees due to lack of financial resources (Cardon\& Stevens, 2004; Bhatti et al., 2012) and their avoidance of complicated recruitment processes to reduce their overheads. In fact, the SMMEs' small operational budgets, infusion of management and ownership roles to reduce operational costs and lack of or a small HR complement, preclude the understanding of the exact impact of financing on the human resource quality of local and foreign-immigrant SMMEs such as hair salons. As such, the influence of private funding on the quality of human resources remains unclear and ambiguous, hence this study. 


\section{Literature Review}

Private financing for SMMEs: Private funding is described as the monetary "support received from commercial banks, retail banks, financial credit schemes, micro lending institutions, personal savings, borrowing from family and friends, individual lending schemes (matshonisas) and community and collective savings (stokvels)" (Rambe \& Mpiti, 2017:106). Despite the diverse private funding options, such as private commercial banks, micro financial institutions, community group savings and individual private lenders (see Rwigema \& Venter, 2004; Mutezo, 2005; Calvin \& Coetzee, 2010; Consultative Group to Assist the Poor, 2012) that are available to SMMEs, the small businesses that are predominantly foreign-owned, such as hair salons, are confronted with multiple challenges such as lack of sufficient collateral, weak (or limited) credit histories (Falkena et al., 2001), lack of financial management records (Rambe \& Mpiti, 2017), high credit risk and a high failure rate (Dzansi, 2004; Agbobli, 2013; Agbotame, 2015). These challenges present small businesses with a dire need for greater financial institution variety, increased innovation and a greater emphasis on financial mentoring (Falkena et al., 2001) for them to increase their breadth of financing, reduce the cost of borrowing and make better choices about responsible spending. The challenge, however, is to locate literature that targets hair salons in particular as most literature focuses on the funding challenges faced by SMMEs in general.

The literature focusing on the private funding of SMMEs emphasises inter alia: the unambitious and limited range of SMME support systems especially the refinancing or guarantee instruments offered by the primary banks (Severino, 2012); bolstering access to finance for female-owned SMMEs (International Finance Corporation 2011); possible public-private partnerships to augment the financing of SMMEs (Timm, 2012) and the breadth and extent of financial credit access in South Africa (Mahembe, 2011). Studies have also documented SMME financial access challenges such as limited awareness; skewed distribution of financial challenges in cities, exorbitant costs of browsing support services and cumbersome administrative processes (Berry et al., 2002; Mahembe, 2011; Mpiti, 2016) and the problematic lumping of small and micro enterprises in the determination of financial options (United Nations Development Programme [UNDP], 2014). However, the nexus between private funding interventions and the quality of human resources of SMMEs still remains a grey area.

SMME human resources: Studies which examine the lack of financial support in SMMEs normally focus on the provision of human resources, accounting and marketing planning training to SMMEs (Small Enterprise Development Agency (SEDA), undated), as well as the need to increase the volume and quality of human resource skills in the industry through knowledge exchange and technology transfer via increased interaction and mobility (Business Partners and Limited and the SME Toolkit South Africa, 2015). The studies often cite the shortage of human resource and business skills, adverse economic conditions, escalating business costs and a hostile regulatory environment as major constraints to the growth prospects of SMMEs in South Africa (UNDP, 2014). Studies have also unpacked the predominantly informal, intuitive and ad hoc character of most SMME human resource processes (Umer, 2012; Sheehan, 2013; Nyamubarwa, 2016) and the way in which the selection of the senior managers is based on family kinship ties [and friendship networks] rather than management skills (Cameron \& Miller, 2008:5). Nevertheless, the human resource practices of SMMEs, especially those of hair salon businesses, remain an underexplored terrain. The existing research has indeed considered contextual and organisational variables, such as firm location, size and duration of existence of the business, and the availability of institutional support and that of an HRM department, which collectively shape the formalisation of human resource processes (Urbano \& Yordanova, 2008; Jan de Kok et al., 2011; Nyamubarwa, 2016) rather than the quality of human resources per se.

Influence of private financing on the SMME human resources: The prominence of SMME human resource issues in recent years (Hussain, Si \& Wang, 2010; Tiwari \& Saxena, 2012; Din et al., 2014; Hung et al., 2016) has tended to ignore the influence private financing on the quality of such SMME human resources. The few exceptions that highlight the financing-human resource relationship tend to emphasise the sequential order in which financing and HRM matters are addressed. Dun, Short and Liang (2008) observe that most SMMEs' commencement of operations is characterised by a focus on financial and marketing aspects of the businesses at the expense of HRM issues. The SMMEs' limited access to financial resources (Levy, 1993) and the higher 
transaction costs they encounter when obtaining credit (Saito \& Villanueva, 1981), may make the location and hiring of right employees a challenge for small businesses (Hull, 2013).

\section{Methodology}

Research design: The research adopted a survey design, in which primary research data was extracted from South African and foreign-owned hair salon businesses located in the Free State province. Surveys are appropriate for research seeking to assess the current status, opinions, beliefs and attitudes of respondents from a known population (McMillan \& Schumacher, 2001). The Industrial Development Corporation and National Youth Development Agency approximated the number of hair salons in the Free State at around 500 (i.e. a known population). A survey was the most ideal in examining hair salon owner/managers' perspectives on the impact of private funding on human resourcing practices of their businesses.

Sample and sampling method: De Vos and Strydom (2005) highlight that a sample of 20\% (i.e. 100 individuals) should be drawn from a total population of 500 individuals. The research, however, catered for low response rates associated with surveys by using a sample of 150 hair salon owner/managers drawn from the population of hair salon businesses in the province. Stratified sampling was also employed owing to the existence of sharp variations in the number of hair salons in the metropole, cities, towns and rural areas. These samples were drawn at each of the noted levels and in proportion to the general population size of those levels.

Measuring instrument and data collection: The study employed a Lickert scale based questionnaire, which comprised closed ended questions. The questions embodied in the measuring instrument emerged from a rigorous review of literature covering the issues under investigation. The instrument had four sections covering sample demographics, the business' profile, private funding and human resources practices and the elements of business competitiveness. Two research assistants assisted the researcher with the collection of data. The survey was administered during the times that were convenient to the hair salon owner/managers. The research team travelled to the different geographical areas to administer the questionnaires, as the small hair salon businesses were spread around in the Free State Province. The self-administration of the questionnaire contributed to the achievement of a high response rate to the survey. Of the 150 questionnaires distributed, 110 were successfully completed and returned, representing a response rate of $73 \%$.

\section{Results}

Data analysis: Data was first entered into excel, cleaned to eliminate incomplete responses and correct errors and exported to the Statistical Package for the Social Sciences (SPSS) version 22 for detailed analysis. Descriptive statistical analysis such as frequency tables (comprising means and percentages) were employed for analysis and presentation of demographic data. Correlation analysis was conducted to determine the relationship between private funding and the quality of human resources of small hair salon businesses. The results of the analysis were presented in correlation tables.

Reliability analysis: A reliability analysis was conducted on constructs in the questionnaire with the summary of the results presented in Table 1 . The table reports on the constructs that are relevant to this study. Except for equity financing, which has a low Chronbach's alpha co-efficient, all the other constructs reflected comparably high alpha coefficients, thus signifying higher levels of reliability. The lower alpha values for equity could be attributed to the fewer items for this construct.

\section{Table 1: Reliability analysis of constructs}

\begin{tabular}{lll}
\hline Construct & Number of items & Alpha value \\
\hline Level of debt financing & 9 & 0.632 \\
Level of equity financing & 4 & 0.478 \\
Recruitment and selection & 11 & 0.875 \\
Compensation & 9 & 0.701 \\
\hline
\end{tabular}


The overall reliability statistics of the entire questionnaire, which include all Likert scaled questions, were also calculated. The Likert scaled questionnaire which had 165 items showed a high internal consistency (Cronbach's Alpha= of 0.937). The Shapiro-Wilk test rejected the normality hypothesis for all the 4 variables (i.e. the level of debt financing, and levels of equity financing, recruitment and selection and compensation). Thus, the non-parametric techniques for assessing group variances on the 4 variables were conducted. The Mann-Whitney U Test was conducted to establish the variations relationships between financing and human resources by nationality of owner/managers. These results are discussed in the findings of the study.

Demographic information: This section provides an overview of the demographic profile of the owner/managers sample. The profile included the gender, age and educational status of the respondents. There was a moderately balanced representation of male hair salon owner/managers (53.6\%) and female owner/managers (46.4\%). The higher representation of males in such business contradicts Mosweunyane's (2013) finding on hair salon owner/management which observed that there were more (60\%) female hair salon owner/managers than male managers (40\%) in the North West Province of South Africa. About 55.5\% of Afro hair salon owner/managers in the Mangaung Metropolitan Area were a youthful population aged between 25-34 years, and these were followed by the 35-44 years group which amounted to $24.5 \%$. Hence, it can be interpreted that a majority (80\%) of the respondents belonged to the economically active population of the nation. The findings somehow corroborates Woldie, Leighton and Adesua's (2008) finding that the younger owner/managers possessed the necessary motivation, energy and commitment to work and were more likely to take business risks than their older counterparts, which was established from their investigation on the business enterprise sector.

There was a fair balance between foreign owner/managers (50.9\%) and South African citizens (48.2\%). This buttresses Kalitanyi and Visser's (2010) claim that foreign-owned SMMEs constitute a significant element of South Africa's changing economy and landscape in the country's different cities. They elaborate that foreign migrant involvement in the nation's SMME sector is predominantly visible in a narrow band of retail and service than in the production sectors. The majority (61.8\%) of the respondents were sole proprietors, while $39 \%$ were partnerships. This probably reflects the technical and financial complexity of establishing other business arrangements, such as private corporations, which demand more technical skills and finance to establish and run sustainably. A sizable percentage (47.3\%) of the businesses had between two and five employees and many businesses (84.5\%) had a turnover of less than R 100 000. In addition, a majority (75.2\%) of the businesses had been in existence for not more than six years. A consideration of these phenomena, therefore, demonstrates the small size and perhaps infancy of the hair salon businesses.

Composition of private financing-a summary: The nature of private financing of Afro hair salons was considered using Likert scale question summaries. These questions were grouped into constructs which were summarised as latent factors that were later used in the inferential analysis. Many hair salons (47.3\%) got their start-up capital from both debt and equity financing. The other businesses got their start-up capital from debt financing only (36.4\%), equity financing only (14.5\%) and from the Sector Education Training Authority (SETA). Debt financing comprised of borrowings from friends and family or from the bank/micro credit institutions. The composition of debit financing, itself a component of private funding, was also disaggregated into various constituents. A majority (52.7\%) of hair salon businesses secured their debt funding from community or group savings, followed by the Matshonisas, individuals mostly located in former black townships who lend money for short durations at high interest rates to borrowers (50.9\%), and then retail banks (50\%). About $47.7 \%$ of hair salon SMMEs had secured debt funding from trade credit, $28.2 \%$ from micro credit schemes and $25.5 \%$ from NGOs.

Extent of Debt Financing: The study explored the extent to which hair salon SMMEs borrowed from various lenders in order to determine the composition of debt financing among these businesses.

Many businesses had not received financing from bootstrapping (79.1\%), NGOs (78.2\%), leasing companies (78.9\%) nor micro credit firms (56.4\%). Most businesses, however, claim to have received funding from Matshonisas, community or group savings and debt financing from banks, which shows that SMMEs have easy access to these forms of financing. 
Equity Financing: The study explored the sources of equity financing available for hair salon SMMEs. A majority (81.8\%) of these businesses considered family and friends as their main source of equity financing. This could be a clear reflection of the easy accessibility and the inexpensive nature of such financial support as these sources may not impose interests on money borrowed by owner/managers. The second highest $(22.7 \%)$ source of equity funding is the contribution from the entrepreneur and team members, which suggests some personal or group investment into these SMMEs. Only $11.8 \%$ of the SMMEs had been financed by business angels while $8.2 \%$ of them had borrowed money from venture capitalists.

Extent of Equity Financing: The study also examined the extent of access to equity funding by interrogating the degree to which SMMEs borrowed from these sources.

Table 2: Level of debt financing

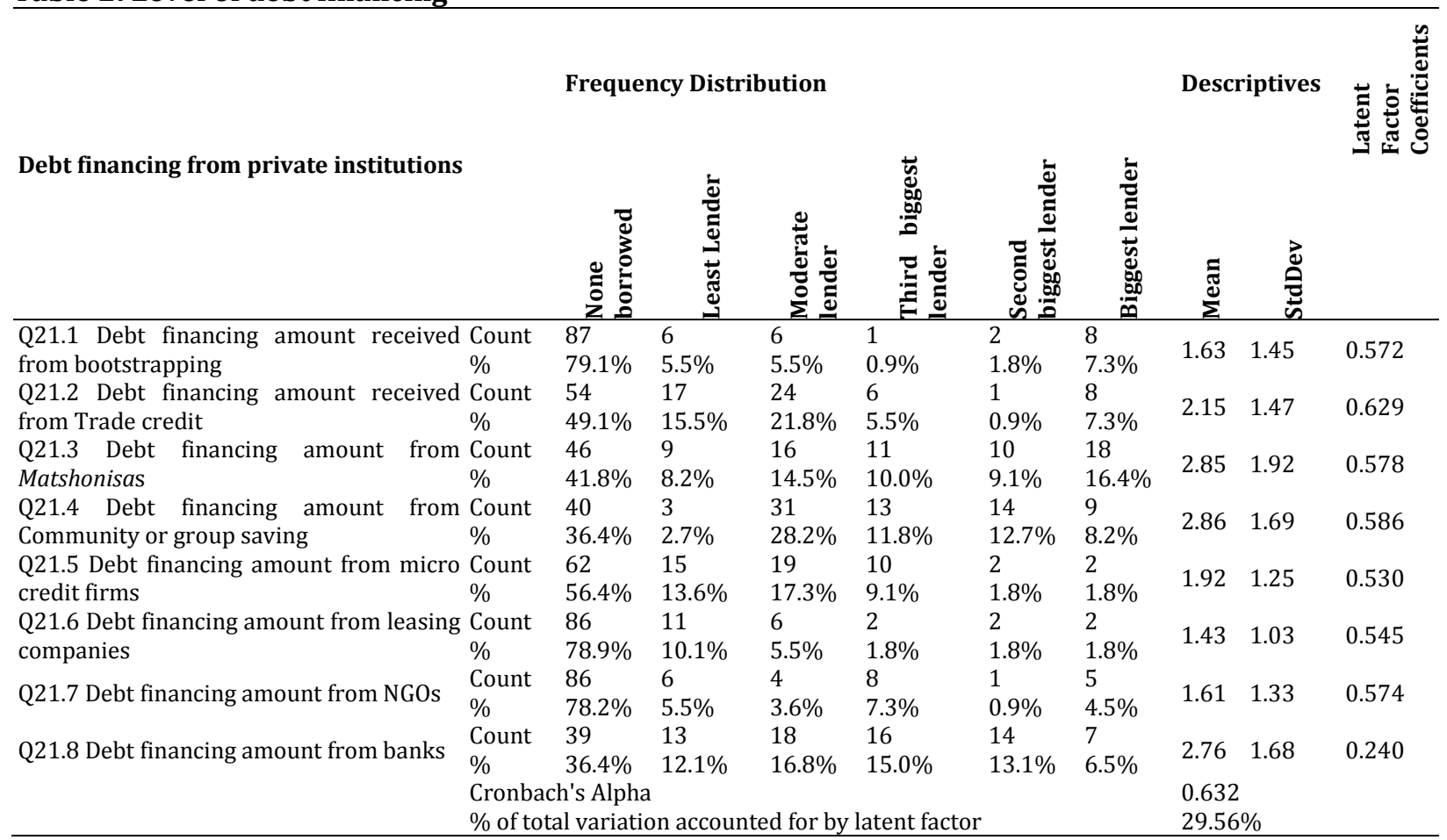

Table 3: Level of equity financing

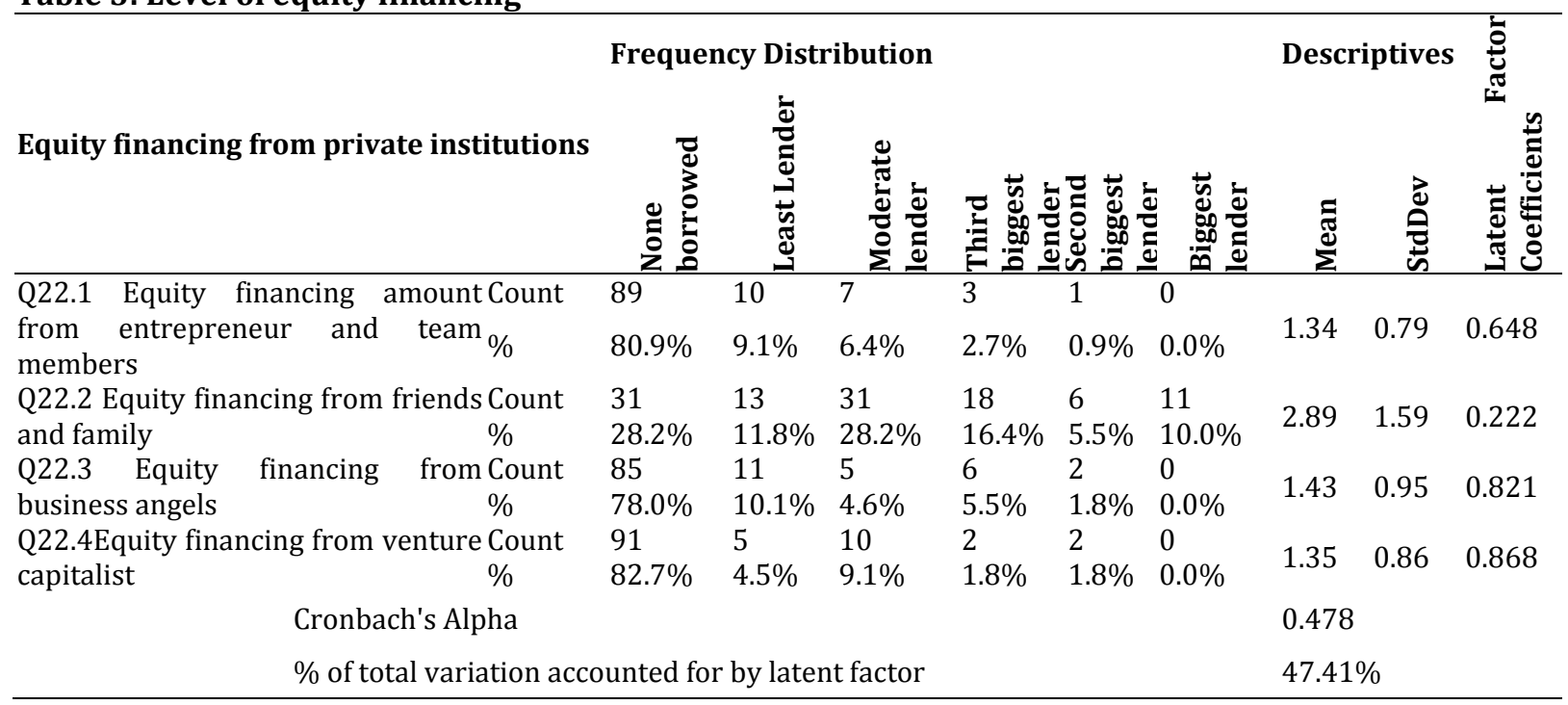


Table 3 indicates that the majority of businesses (82.7\%) did not receive equity financing from venture capitalists. Venture capitalists are often reluctant to invest their money in SMMEs due to their high risk of failure. The findings suggest that most business (80.9\%) did not receive equity financing from entrepreneurs and team members. This is surprising as entrepreneurs and team members would be expected to invest in their SMME business over and above different forms of borrowings. Most SMMEs $(78.0 \%)$ did not receive equity funding from business angels. A business angel is an individual funder who finances someone's businesses but prefer to keep his/her identity unknown to the general public. It can be assumed that most business angels are reluctant to invest in high risk businesses for fear of losing their money. The high failure rate of new start-ups explains both the general unwillingness of these business angels to invest in SMMEs and their risk averse behaviour. Nevertheless, equity financing came mainly from friends and family (31.9\%) - a clear indication of significance of donations/support from family or friends.

Human resources management practices of hair salons: The study also examined the HRM practices of hair salon business before relating them to funding. The practices considered here included recruitment, selection, training, development and compensation.

HR Recruitment and selection: The study investigated whether small businesses followed the proper procedures when recruiting and selecting their personnel. The results are presented in Table 4 below.

Table 4: HR recruitment and selection

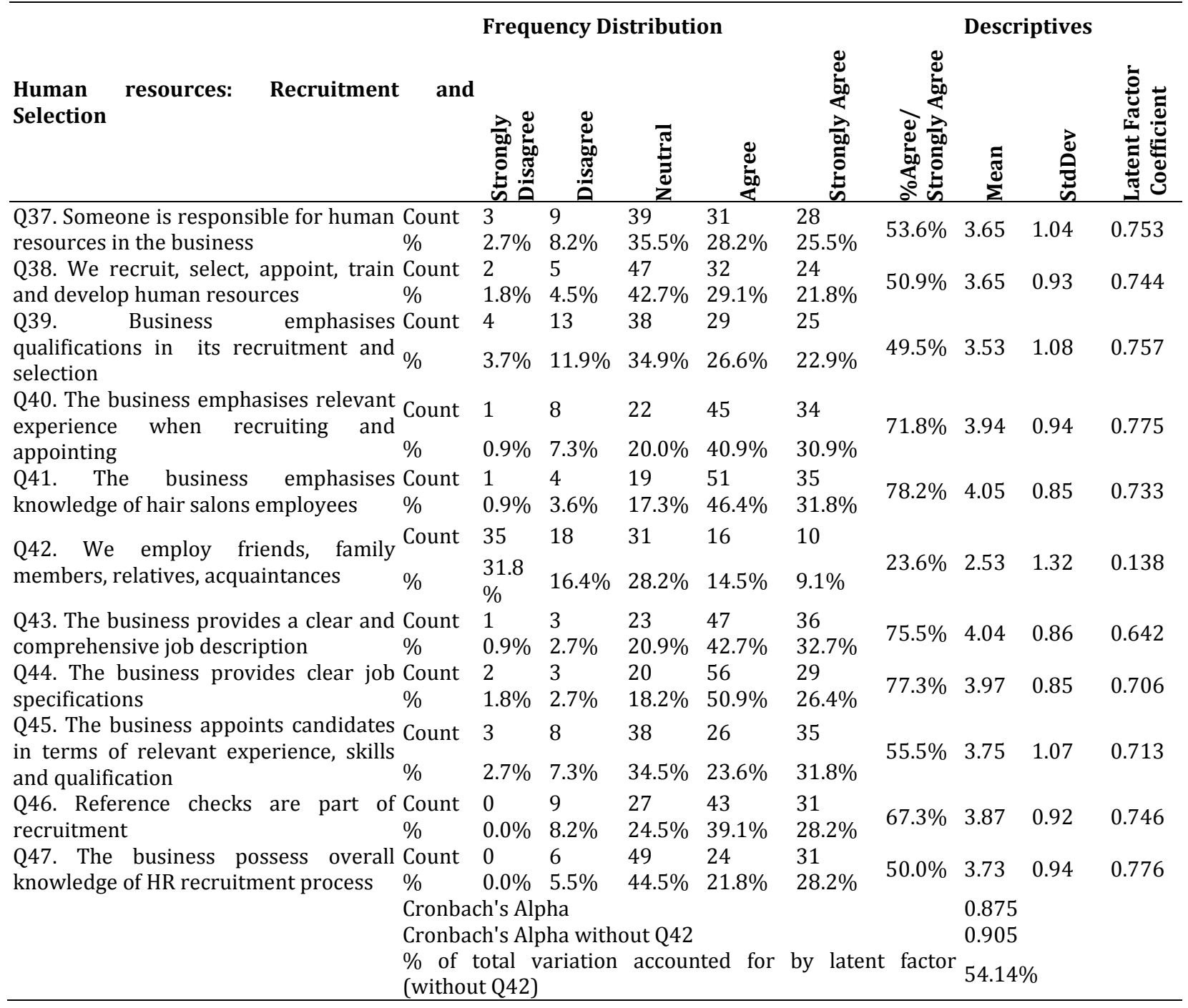


A majority (71.8\%) of hair salons prioritise the possession of relevant experience when selecting prospective employees, while $49.5 \%$ claimed that their businesses emphasised the possession of qualifications during employee selection. The fact that most hair salon businesses rely more on technical hand work than academic knowledge might explain the less emphasis on prospective employees' academic qualifications. Business knowledge of hair salon employees $(78.2 \%)$ and reference checks $(67.3 \%)$ were constitutive components of the selection criteria of employees of hair salons. The high percentages on knowledge of the hair salon industry and employee reference checks is commendable. However, hair salon businesses have complicated HR practices. For instance, while it was observed that many provide clear job descriptions $(75 \%)$ and job specifications $(77.3 \%)$ to employees, some owner/managers $(23 \%)$ admitted to hiring family members and acquaintances, which is a problematic HR practice.

HR Compensation: The study also investigated the way employees are compensated and whether access to private funding influences human resources practices within small businesses.

Table 5: HR compensation

\begin{tabular}{|c|c|c|c|c|c|c|c|c|c|c|}
\hline \multirow{2}{*}{ Human resources: Compensation } & \multicolumn{7}{|c|}{ Frequency Distribution } & \multicolumn{3}{|c|}{ Descriptives } \\
\hline & & 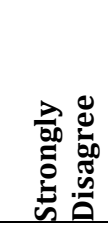 & 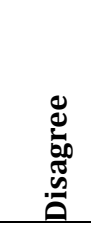 & Z & 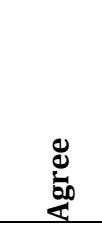 & 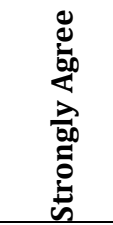 & 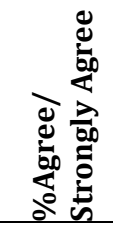 & $\sum_{\Sigma}^{\Xi}$ & 离 & 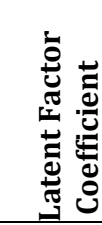 \\
\hline \multirow{2}{*}{$\begin{array}{l}\text { Q48. Salaries are in accordance with } \\
\text { labour market standards }\end{array}$} & Count & 1 & 7 & 17 & 33 & 52 & \multirow[b]{2}{*}{$77.3 \%$} & \multirow[b]{2}{*}{4.16} & \multirow[b]{2}{*}{0.97} & \multirow[b]{2}{*}{0.472} \\
\hline & $\%$ & $0.9 \%$ & $6.4 \%$ & $\begin{array}{l}15.5 \\
\%\end{array}$ & $30.0 \%$ & $47.3 \%$ & & & & \\
\hline \multirow{2}{*}{\multicolumn{2}{|c|}{$\begin{array}{l}\text { Q49. Employees are registered for } \begin{array}{c}\text { Count } \\
\text { income tax }\end{array} \\
\%\end{array}$}} & 39 & 25 & 12 & 22 & 12 & \multirow[b]{2}{*}{$30.9 \%$} & \multirow[b]{2}{*}{2.48} & \multirow[b]{2}{*}{1.43} & \multirow[b]{2}{*}{-0.398} \\
\hline & & $35.5 \%$ & $\begin{array}{l}22.7 \\
\%\end{array}$ & $\begin{array}{l}10.9 \\
\%\end{array}$ & $20.0 \%$ & $10.9 \%$ & & & & \\
\hline \multirow{2}{*}{\multicolumn{2}{|c|}{$\begin{array}{l}\text { Q50. Employees are compensated Count } \\
\text { according to hours of work }\end{array}$}} & 8 & 18 & 20 & 29 & 35 & \multirow[b]{2}{*}{$58.2 \%$} & \multirow[b]{2}{*}{3.59} & \multirow[b]{2}{*}{1.29} & \multirow[b]{2}{*}{0.317} \\
\hline & & $7.3 \%$ & $\begin{array}{l}16.4 \\
\%\end{array}$ & $\begin{array}{l}18.2 \\
\%\end{array}$ & $26.4 \%$ & $31.8 \%$ & & & & \\
\hline \multirow{2}{*}{\multicolumn{2}{|c|}{$\begin{array}{l}\text { Q51. Access to private funding } \begin{array}{l}\text { Count } \\
\text { influences employee training }\end{array}\end{array}$}} & 10 & 8 & 34 & 33 & 25 & \multirow[b]{2}{*}{$52.7 \%$} & \multirow[b]{2}{*}{3.50} & \multirow[b]{2}{*}{1.19} & \multirow[b]{2}{*}{0.772} \\
\hline & & $9.1 \%$ & $7.3 \%$ & $\begin{array}{l}30.9 \\
\%\end{array}$ & $30.0 \%$ & $22.7 \%$ & & & & \\
\hline \multirow{2}{*}{$\begin{array}{l}\text { Q52. Access to private funding } \\
\text { influences retention of employees }\end{array}$} & Count & 12 & 13 & 41 & 23 & 21 & \multirow[b]{2}{*}{$40.0 \%$} & \multirow[b]{2}{*}{3.25} & \multirow[b]{2}{*}{1.21} & \multirow[b]{2}{*}{0.841} \\
\hline & $\%$ & $10.9 \%$ & $\begin{array}{l}11.8 \\
\%\end{array}$ & $\begin{array}{l}37.3 \\
\%\end{array}$ & $20.9 \%$ & $19.1 \%$ & & & & \\
\hline \multirow{2}{*}{$\begin{array}{l}\text { Q53. Access to private funding } \\
\text { influences employee compensation }\end{array}$} & Count & 10 & 19 & 25 & 36 & 20 & \multirow[b]{2}{*}{$50.9 \%$} & \multirow[b]{2}{*}{3.34} & \multirow[b]{2}{*}{1.22} & \\
\hline & & $9.1 \%$ & $\begin{array}{l}17.3 \\
\%\end{array}$ & $\begin{array}{l}22.7 \\
\%\end{array}$ & $32.7 \%$ & $18.2 \%$ & & & & 0.759 \\
\hline Q54. Employee pay rates are ke & Count & 1 & 1 & 16 & 36 & 56 & & & & \\
\hline $\begin{array}{l}\text { Q54. Empioyee pay rates are Kept } \\
\text { confidential }\end{array}$ & & $0.9 \%$ & $0.9 \%$ & $\begin{array}{l}14.5 \\
\%\end{array}$ & $32.7 \%$ & $50.9 \%$ & $83.6 \%$ & 4.32 & 0.82 & 0.734 \\
\hline 055. Employee salary is determined & Count & 9 & 19 & 30 & 33 & 19 & & & & \\
\hline based on comparison with competitors & $\%$ & $8.2 \%$ & $\begin{array}{l}17.3 \\
\%\end{array}$ & $\begin{array}{l}27.3 \\
\%\end{array}$ & $30.0 \%$ & $17.3 \%$ & $47.3 \%$ & 3.31 & 1.19 & 0.427 \\
\hline 056 Salary ranges are used & Count & 2 & 2 & 28 & 45 & 32 & & & & \\
\hline determine salary rates & $\%$ & $1.8 \%$ & $1.8 \%$ & $\begin{array}{l}25.7 \\
\%\end{array}$ & $41.3 \%$ & $29.4 \%$ & $70.6 \%$ & 3.94 & 0.89 & 0.683 \\
\hline & Cronba & ch's Alpl & & & & & & 0.701 & & \\
\hline & Cronba & ch's Alph & la (whe & n Q49 & omitte & & & 0.795 & & \\
\hline & $\begin{array}{l}\% \text { of } t \\
\text { (Q49 ex }\end{array}$ & $\begin{array}{l}\text { otal var } \\
\text { cluded) }\end{array}$ & iation & accou & ed for & by laten & t factor & 43.04 & & \\
\hline
\end{tabular}


A majority (83.6\%) of hair salons held the opinion that their businesses keep employee records confidential and that salary ranges are used to determine salary rates (70.6\%). However, the businesses displayed complex organisational processes. The majority $(77.3 \%)$ of the respondents claim that their companies offer market-related salaries and only 30\% confirmed that their employees are registered for income tax payments. In addition, more than half (58\%) of the respondents claimed that their employees are paid according to the hours they worked. Hair salons owner/managers offer more or less the same salaries as other hair salons. A total of $40 \%$ of the firms believed that access to private funding influences the training of employees and $50.9 \%$ professed that access to private funding influences employee compensation. Having access to private funding allows the owner/manager to take their employees for training to improve their skills and pay their salaries.

Debt financing by nationality: A Mann-Whitney two-sample rank-sum test was conducted to examine whether there were significant differences in debt financing between the levels of nationality. The MannWhitney two-sample rank-sum test is a non-parametric alternative to the independent samples $t$-test, which does not share the independent samples $t$-test's distributional assumptions (Conover \& Iman, 1981). There were 53 observations in group SA_Citizen and 57 observations in group SA_Non_Citizen (see Table 6). The results of the Mann-Whitney $U$ test were not significant, $U=1370, z=-0.84, p=.399$. The mean rank for group SA_Citizen was 52.85 and the mean rank for group SA_Non_Citizen was 57.96. This suggests that the distribution of debt_financing for group SA_Citizen is not significantly different from the distribution of debt_financing for the group SA_Non_Citizen. This probably shows that both South African citizens and foreign nationals encounter the same lending conditions from debtors such as family members, friends and business angels. Table 6 presents the results of the Mann-Whitney $U$ test.

Table 6: Mann-Whitney Rank Sum Tests for debt financing, equity financing, recruitment and section and compensation by nationality of hair salon owner/managers

\begin{tabular}{|c|c|c|c|c|c|}
\hline Variable & $\begin{array}{l}\text { Mean Rank } \\
\text { SA_Citizen }\end{array}$ & SA_Non_Citizen & $\boldsymbol{U}$ & $\boldsymbol{Z}$ & $p$ \\
\hline Debt_financing_ & $\begin{array}{l}52.85 \\
\text { Mean Rank }\end{array}$ & 57.96 & 1370.00 & -0.84 & 0.399 \\
\hline Variable & SA_Citizen & SA_Non_Citizen & $U$ & $z$ & $p$ \\
\hline Equity_financing & $\begin{array}{l}49.72 \\
\text { Mean Rank }\end{array}$ & 60.88 & 1204.00 & -1.86 & .063 \\
\hline Variable & SA_Citizen & SA_Non_Citizen & $U$ & $z$ & $p$ \\
\hline $\begin{array}{l}\text { Recruitment and } \\
\text { Selection_ }\end{array}$ & 67.82 & 44.04 & 2163.50 & -3.92 & $\begin{array}{l}< \\
0.001\end{array}$ \\
\hline $\begin{array}{l}\text { Variable } \\
\text { Compensation }\end{array}$ & $\begin{array}{l}\text { Mean Rank } \\
\text { SA_Citizen } \\
59.09\end{array}$ & $\begin{array}{l}\text { SA_Non_Citizen } \\
52.16\end{array}$ & $\begin{array}{l}U \\
1701.00 \\
\end{array}$ & $\begin{array}{l}Z \\
-1.14 \\
\end{array}$ & $\begin{array}{l}P \\
0.253 \\
\end{array}$ \\
\hline
\end{tabular}

Equity_financing by nationality: A Mann-Whitney two-sample rank-sum test was conducted to examine whether there were significant differences in equity financing between the levels of nationality. There were 53 observations in group SA_Citizen and 57 observations in group SA_Non_Citizen (see Table 6). The results of the Mann-Whitney $U$ test were not significant, $U=1204, z=-1.86, p=.063$. The mean rank for group SA_Citizen was 49.72 and the mean rank for group SA_Non_Citizen was 60.88. This suggests that the distribution of equity_financing for group SA_Citizen is not significantly different from the distribution of equity_financing for group SA_Non_Citizen.

Recruitment and selection by nationality: A Mann-Whitney two-sample rank-sum test was conducted to examine whether there were significant differences in recruitment and selection between the levels of nationality. There were 53 observations in group SA_Citizen and 57 observations in group SA_Non_Citizen (see Table 6). The results of the Mann-Whitney $U$ test were significant, $U=2163.5, z=-3.92, p<.001$. The mean rank for group SA_Citizen was 67.82 and the mean rank for group SA_Non_Citizen was 44.04. This suggests that the distribution of recruitment and selection for group SA_Citizen is significantly different from the distribution of recruitment and selection for group SA_Non_Citizen. The difference in recruitment and selection in the two levels of nationality is perhaps the result of the South African sample's acquaintance with a well-established labour regulation regime and the efficiency driven nature of their economy. In contrast, the 
SA Non-citizen sample may not be sufficiently grasping the labour laws that affect recruitment and selection and the risks associated with non-compliance with these regulations.

Compensation by Nationality: A Mann-Whitney two-sample rank-sum test also determined whether there were significant differences in compensation between the levels of nationality. There were 53 observations in group SA_Citizen and 57 observations in group SA_Non_Citizen, as shown in Table 6 outlining the results from the Mann-Whitney $U$ test. The results of the Mann-Whitney $U$ test were not significant, $U=1701, z=-1.14, p=$ .253. The mean rank for group SA_Citizen was 59.09 while that for group SA_Non_Citizen was 52.16. This suggests that the distribution of compensation for group SA_Citizen is not significantly different from the distribution of compensation for group SA_Non_Citizen. The familiarity of each group with the compensation structures of the other group (due to the informality of the HRM systems) probably explains their almost identical rewarding systems.

Effects of private funding on human resources: The correlation analysis method was also used to determine the nature of the relationship between private funding and human resources. Table 7 below presents the correlations between the various private funding variables, discussed in the previous sections, and the already discussed human resources variables.

Table 7: Correlations between private funding and human resources

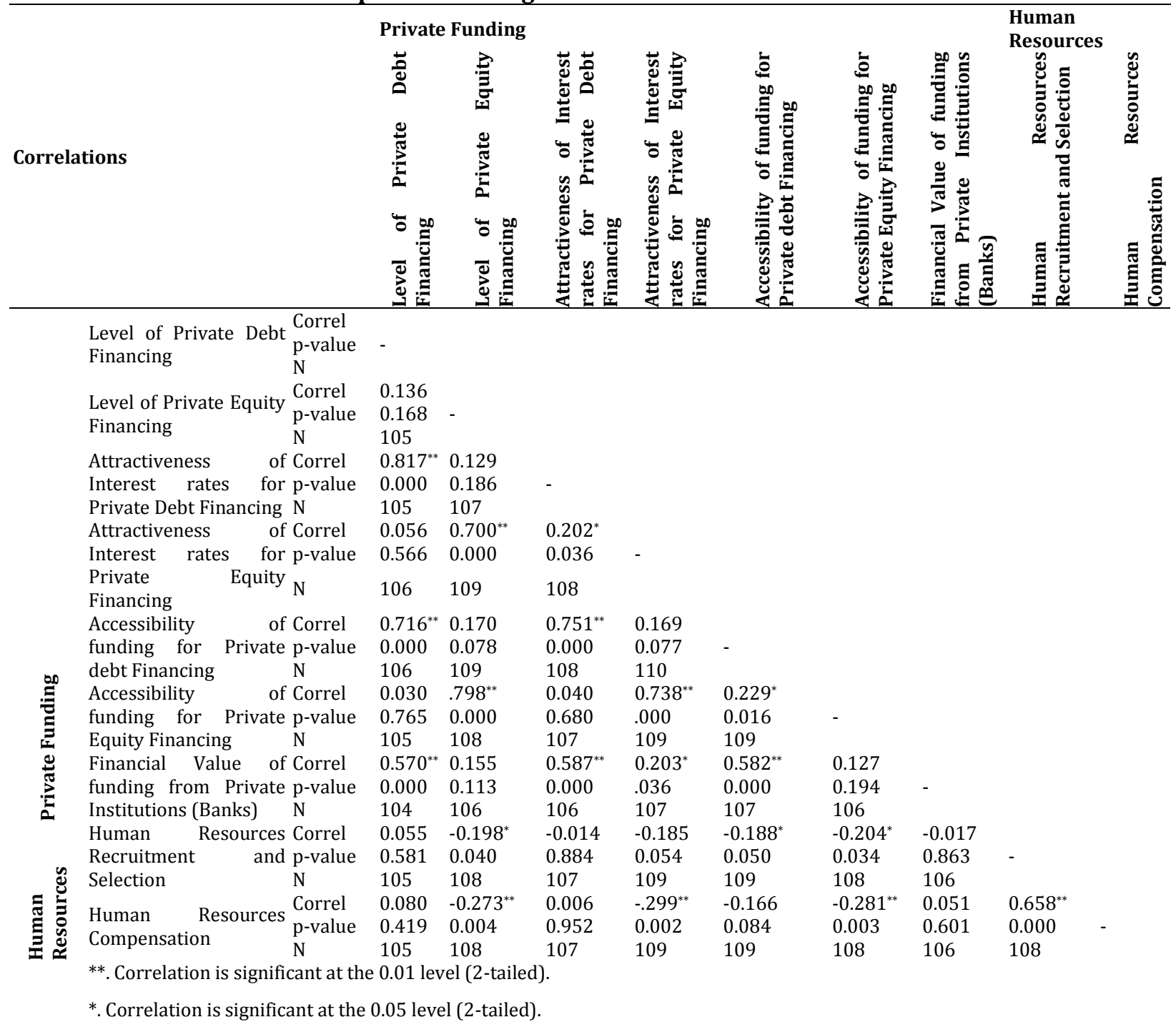


Private funding and human resources: The accessibility of funding for private equity financing has a significant negative impact on recruitment and selection (correlation=-0.204, p-value=0.034) and compensation (correlation $=-0.281$, $\mathrm{p}$-value $=0.003$ ). This contradicts claims that the availability of financial resources is critical for an improved recruitment and selection of an enterprise's employees. The results in Table 7 show that the level of private debt financing, attractiveness of private debt financing interest rates and the value of funding from private institutions (banks) do not have any impact on the human resources management two constructs of recruitment and selection, and compensation (small correlations and pvalues $>0.05$ ). The level of private equity financing has a negative impact on recruitment and selection (correlation=-0.198, p-value $=0.040$ ) and compensation (correlation=-0.273, p-value=0.004). The attractiveness of interest rates for private equity financing has a negative impact on compensation (correlation $=-0.299, \mathrm{p}$-value $=0.002$ ). The accessibility of funding for private debt financing has a negative impact on recruitment and selection (correlation $=-0.188$, $p$-value $=0.050$ ). Therefore, it is important to note that, while some aspects of private finance have a negative impact on human resources management, the effect size of such an impact is very minimal, for none of the absolute correlation values are greater than 0.300. Thus, the general observation is that private funding has a limited impact on human resources management.

Discussion-SMME Financing: While a combination of debt and equity comprised almost half (47.3\%) of the total financing for small businesses, debt financing was considerably higher than equity financing, thus demonstrating the small businesses' complexities in generating funding internally. This finding corroborates evidence from literature where the low equity capital generation capacity of small firms is identified as a major constraint to the growth of small firms (International Finance Corporation 2011; Severino, 2012). Severino (2012) affirms that SMMEs' equity capital constraints are a consequence of their owners' financial incapability, which forecloses their access to financial opportunities and business growth potential. Our finding contradicts Fatoki's (2014) claim that South African SMME operations can enhance their credibility when sourcing funding externally by first seeking internal equity before considering other funding sources.

In terms of debt financing, most hair salon SMMEs relied heavily on Matshonisa (private individual lenders) and community or group savings to finance their businesses. The popularity of these funding sources stems from their perceivably relaxed lending procedures, especially the exclusion of collateral from borrowers. While this finding resonates with the claim by Falkena et al. (2001) that non-bank financial intermediaries play a significant role in SMME enterprise lending, the same finding contradicts their claim that these intermediaries are imposing constraints on SMMEs' lines of credit. Our finding is, nevertheless, consistent with the reality that South Africa's black-owned businesses rely more on informal financial options, such as Matshonisas, community savings and funeral and burial schemes as such businesses are financially excluded by formal financial institutions such banks (SEDA, undated).

Banks were sometimes another credible source of funding as noted in the 50\% of SMMEs that borrowed from the banks. This finding is surprising and somewhat contradicts conventional wisdom about SMMEs' complexities of accessing finance from retail and commercial banks due to lack of tangible assets or collateral (Gichuki, Njeru \& Tirimba, 2014; Mwaka, 2014; Mpiti, 2016). Alternatively, this points to local banks' diversification of their funding portfolios to include pro-poor lending, even though they may be extending small amounts of credit to reduce their risk vulnerability. Many hair salons had not received funding from bootstrapping, NGOs, leasing companies and micro credit firms. Perhaps, this scenario can be attributed to insufficient information about their funding procedures due to their poor marketing or the associated high costs of borrowing. In addition, the dominance of national and provincial government agencies that provide loan facilities to SMMEs, such as the National Youth Development Agency, SEDA and Small Enterprise Finance Agency (SEFA), may eclipse the visibility of the aforesaid funding modalities (Small Enterprise Finance Agency, 2015).

With regard to equity, borrowing from family and friends constituted the prime forms of lending, while borrowing from entrepreneurs and team members, business angels and venture capitalist were the least represented. While this evidence signifies the equity problem, it contradicts Mason and Harrison's (2013) observation that entrepreneurs and team members may invest their assets in high risk-high return enterprises in exchange for the firm's equity. Our findings buttresses literature, which suggests that national 
institutions should increase financial stimulus for small businesses due to the reluctance of venture capitalists and business angels to support emerging businesses and SMMEs' high risk of failure (Falkena, 2001; Cobbett, 2008). The same findings resonate with Timm's (2012) claim that unlike other emerging markets such as Chile and Malaysia, which are increasing angel investment networks by funding businesses through angel investors' collaboration with state entities to mitigate the risk of investing in small business entities, South Africa lacks a business angel-investing environment.

Human resourcing practices: Hair salon businesses had complicated HRM practices. For instance, the possession of relevant experience was noted as an integral requirement for their recruitments, even though they did not hire highly educated employees. The reluctance or inability to hire highly educated personnel is inconsistent with the recognition that educated personnel are more productive and have more learning and innovative abilities (Batra \& Tan 2003; Hussain, Si \& Wang, 2010). Our findings on the recruitment of people with lower education attainments cohere with observations on the low human resource capabilities of SMMEs, especially qualification-job match, which constrain the SMMEs' development in emerging economies (Hussain, Si \& Wang, 2010). Hair salons' deployment of trained personnel, however, resonates with Onsongo's (2015) study on factors influencing the growth of hair salon enterprises in Kisii Town, Kenya, which reported that the hair salons require highly trained and knowledgeable staff that keeps abreast with industry demands and offer quality products and services.

The finding on many SMME owner/managers' engagement in HRM practices is inconsistent with the literature on SMMEs. Lockyer and Scholaries (2005) revealed a general lack of systematic procedures for employee resourcing and a limited tradition of legitimate human resource practices within SMMEs. In addition, the owner/managers' claim that they paid their employees market competitive salaries demonstrates their businesses' compliance with national labour relations. The Government Notice Report on Bargain Council for hairdressing, cosmetology beauty and skincare states that no employer shall pay and no employee shall accept a salary lower than the prescribed national minimum salary for that trade/profession (Oliphant, 2013).

Relationship between financing and human resource practices: The accessibility of funding for private equity and debt financing has a significant negative impact on recruitment and selection, and compensation. This contradicts Hussain, Si and Wang's (2010) finding that access to financial resources is integral to the development of an effective technical and HR programme, which is vital for the development of small enterprises. The findings also contradict the Board of Governors of the Federal Reserve Systems Report (2012) finding that the provision of equity is fundamental to a healthy and thriving human resource compliment. The levels of private debt financing, attractiveness of interest rates for private debt financing and financial value of funding from private institutions (banks) do not have any impact on the two constructs of human resources management, namely, recruitment and selection, training and compensation (small correlations and p-values>0.05). Since the dominant forms of debt financing were from banks and from community group savings, it could argue that these institutions are loaning SMMEs small amounts, which do not impact considerably on the businesses' recruitment and compensation processes. The risk averseness of banks is well documented (Fatoki, 2014; Mpiti, 2016; SEDA, undated). In the same vein, community group savings also involve small amounts, which may be inconsequential to the human practices of SMMEs.

The level of private equity financing has a negative impact on recruitment and selection and compensation. The reality that family members and friends provided private equity funding suggests that these lenders can demand equity from the businesses either as co-owners/managers or demanding competitive salaries. This interpretation on hiring family and friends contradicts Kanu's (2015) finding on Sierra Leone SMMEs' engagement in formal HRM practices, which were observed as positively influencing the HR development and sales. The current study demonstrates that the attractiveness of interest rates for private equity financing has a negative impact on compensation. Perhaps, attractive interest rates compel owner/managers to recoup profits, which they in-turn channel to quick loan repayments. This may mean that SMME employees end up as the victims of their success as money intended for their competitive salaries gets diverted to repay loans. 


\section{Conclusion}

The current study interrogated the three issues: (1) the constitution of private funding options available to resource-constrained foreign and locally owned hair salon businesses, (2) the quality of the human resources of the SMMEs and (3) the relationship between private funding and human resources practices. Almost half of the hair salons surveyed with regard to the constitution of private funding, employed a combination of both debt and equity funding. However, a sizable percentage of SMMEs relied on debt financing after equity and debt financing had been disaggregated, while a small percentage employed equity capital. This demonstrates the complexity of generating equity financing internally and contradicts the firm life-cycle theory that emphasises the need for small firms to generate financial resources internally for their increased growth before resorting to debt financing. Hair salons' dependence on family members and friendship networks for debt financing also demonstrates the constricted sources of external financing for SMMEs. As a result, SMMEs collectively need a more conductive economic environment for the diversification of their internal and external sources of funding. To this effect, venture capital and business angels are strong, under-exploited avenues that the South African government can strengthen through increased public-private partnerships with these financiers to share and externalise risks for small businesses.

Although small businesses appointed well experienced staff and remunerated them competitively, they also displayed unsophisticated recruitment practices, such as recruiting family members/friends and personnel with low educational attainments. This, at face value, may not be a problem in view of the fact that hair salon related tasks may not necessarily require tertiary level attainments, innovation, productivity and open learning requirements of firms, but it is common knowledge that enterprises may be compromised by the use of such cheap labour. The diversification of funding and pursuit of higher education attainments by hair salon owner/managers themselves could be the entry point to the development of the educational threshold for the SMME work force. While accessibility of funding for debt financing has a positive but insignificant impact on recruitment and selection and point to the capacity of funding to leverage HRM practices of hair salons, all the other private finance-HRM relationships were negative. The reality that the level of private debt financing, attractiveness of interest rates for private debt financing and the financial value of funding from private institutions (banks) do not have any impact on the human resources management constructs (i.e. recruitment and selection, and compensation), may imply different issues. These include the insufficiency of funds borrowed for overhauling HRM practices or the possible diversion of funds intended for salary increments to debt servicing leading to stagnancy of salary levels. Hence, the diversity of pro-poor funding sources meant for SMMEs would contribute to the overhaul of their HRM practices.

Acknowledgements: The financial assistance of the National Research Foundation (NRF) towards this research is hereby acknowledged. Opinions expressed and conclusions arrived at, are those of the author and are not necessarily to be attributed to the NRF.

\section{References}

Agbobli, E. K. (2013). The influence of entrepreneurial and market orientations on small scale rural agricultural enterprises in the Vryburg area. PhD Thesis, Central University of Technology, Free State.

Agbotame, L. (2015). Impact of selected globalisation aspects on the performance of small scale agro- based businesses in typical South African rural settings. PhD Thesis, Central University of Technology, Free State.

Aldrich, H. \& Von Glinow, M. A. (1991). Business starts-ups: The HRM imperative. In S. Subramony (Ed.), International perspectives on entrepreneurship research (pp. 233-253). New York: Elsevier Publications.

Almeida, S., Fernando, M., Hannif, Z. \& Dharmage, S. (2015). Fitting the mould: the role of employer perceptions in immigrant recruitment decision-making. The International Journal of Human Resource Management, 26(22), 2811-2832. http://dx.doi.org/10.1080/09585192.2014.1003087

Aytaç, E., Mousseau, M. \& Örsün, Ö. (2014). Why some countries are immune from the resource curse: The role of economic norms, Democratization, http://dx.doi.org/10.1080/13510347.2014.964216

Barrett, L. F. (2004). Feelings or words? Understanding the content in self-report ratings of experienced emotion. Journal of Personality and Social Psychology, 87, 266-281. 
Batra, G. \& Tan, H. (2003). SME Technical Efficiency and Its Correlates: Cross-National Evidence and Policy Implications, World Bank Institute Working info.worldbank.org/etools/docs/.../ses3.1_smetechefficiency.pdf

Beck, T., Fuchs, M. J. \& Uy, M. (2009). Finance in Africa - achievements and Challenges. World Bank Policy Research Working Paper Series.

Berry, A., Von Blottnitz, M., Cassim, R., Kesper, A., Rajaratriam, B. \& Van Seventer, D. E. (2002). The Economics of SMMES in South Africa [Online]. Available: http://citeseerx.ist.psu.edu/viewdoc/download?doi=10.1.1.473.1840\&rep=rep1\&type=pdf

Bhatti, N., Syed, A., Shah, S., Faiz, M. \& Shaikh, F. (2012). Human Resource Management and SMEs Business Growth in Pakistan. Asian Social Science, 8(6), 136-139.

Blackburn, R. A., Hart, M. \& Wainwright, T. (2013). Small business performance: business, strategy and owner-manager characteristics. Journal of Small Business and Enterprise Development, 20(1), 8-27.

Board of Governors of the Federal Reserve System. (2012). Report to the Congress on the Availability of Credit to Small Businesses [Online]. Available: http://www.federalreserve.gov/publications/otherreports/files/sbfreport2012.pdf[2015, October 20].

Business Partners Limited and the SME Toolkit South Africa. (2015). Helping you to start, manage and grow your business http://southafrica.smetoolkit.org/sa/en

Calvin, B. \& Coetzee G. (2010). Review of the South African Microfinance Sector Volume II Section IV: Special Products. University of Pretoria - Centre for Micro Finance. http://web.up.ac.za/sitefiles/file/1/3841/Volume\%20II\%20Section\%20IV\%20Special\%20Products .Pdf

Cardon, M. S. \& Stevens, C. E. (2004). Managing human resources in small organizations: What do we know? Human Resource Management Review, 14(3), 295-323.

Cameron, L. \& Miller, P. (2008). Enhancing HRM practice in SMEs using the concept of relationship marketing. Melbourne: Southern Cross University.

Chimucheka, T. \& Mandipaka, F. (2015). Challenges faced by small, medium and micro enterprises in the Nkonkobe Municipality. The International Business \& Economics Research Journal, 14(2), 309-316.

Cobbett, W. (2008). What is venture capital [Online]? Available: http://www.smoothridetoventurecapital.com/P1.C01_What.is.Venture.Capital.pdf[2015, July 22]

Conover, W. J. \& Iman, R. L. (1981). Rank transformations as a bridge between parametric and nonparametric statistics. American Statistician, 35, 124-129.

Consultative Group to Assist the Poor. (2012). Advancing financial access for the world's poor. Annual Report, Washington http://documents.worldbank.org/curated/en/616911468320667224/pdf/75163020120CGA0Box0 374307B00PUBLIC0.pdf

Davis, N. \& Luiz, J. (2015). The Devolution of the Human Resources Function in South African Multinational Companies. The International Journal of Human Resource Management, 26(21), 2763-2785.

Davidsson, P. \& Honig, B. (2003). The role of social and human capital among nascent entrepreneurs. Journal of Business Venturing, 18(3), 301-331.

Davies, R. \& Thurlow, J. (2009). Formal-Informal Linkages and Unemployment in South Africa. Human Sciences Research Council.

Demacon Market Studies. (2010). Chapter Twelve: Impact of Township Shopping Centres on local businesses and informal trade. July, 2010.

De Vos, A. S. \& Strydom, H. F. (2005). Research at Grass Roots: For the social sciences and human service professions. Cape Town: Juta

Din, S., Bibi, Z., Karim, J. \& Bano, A. (2014). HRM Practices Can Do the Miracles: A Case Study of Pharmaceutical Companies. Pakistan Journal of Social Sciences, 34(2), 637-652.

Dunn, P., Short, L. E. \& Liang, K. (2008). Human resource management importance in small business. Small Business Institute Journal, 2, 1-22.

Dzansi, D. Y. (2004). Social Responsibility of SMMEs in Rural Communities. Unpublished Doctoral dissertation, Pretoria: University of Pretoria.

Falkena, H., Abedian, I., von Blottnitz, M., Coovadia, C., Davel, G., Madungandaba, J., Masilela, E. \& Rees, S. (2001). SMEs' access to finance in South Africa - A supply-side regulatory review. The Task Group of the Policy Board for Financial Services and Regulation. Treasury Department, Republic of South Africa. 
Fatoki, O. (2014). The Financing Options for New Small and Medium Enterprises in South Africa. Mediterranean Journal of Social Sciences, 5(20), 120-127.

Gichuki, J. A. W., Njeru, A. \& Tirimba, O. I. (2014). Challenges Facing Micro and Small Enterprises in Accessing Credit Facilities in Kangemi Harambee Market in Nairobi City County, Kenya. International Journal of Scientific and Research Publications, 4(12), 1-25.

Horwitz, F. M. (2013). Human Resource Management in Southern Africa Multinational Firms: Considering an Afro-Asian Nexus. A. Newenham-Kahindi, K. N. Kamoche, A. Chizema, K. Mellahi (Eds.) Effective People Management in Africa (pp. 126-151). Palgrave McMillan

Hung, Y. T., Cant, M. \& Wiid, J. (2016). The importance of human resource management for small businesses in South Africa. Problems and Perspectives in Management, 14(3), 232-238.

Hull, P. (2013). Hire slow, fire fasthttp://www.forbes.com/sites/patrickhull/2013/03/27/hire-slow-firefast/\#78f8c9573cb7

Hurst, E. \& Lusardi, A. (2004). Liquidity Constraints, Household Wealth, Entrepreneurship. Journal of Political Economy, 112(2), 319-47.

Hussain, I., Si, S. \& Wang, L. (2010). SMEs Development in Developing Countries through Public - Private Partnership www.ceauk.org.uk/2010-conference-papers/full.../Iftikhar-Hussain-CEA-final.pdf

Horwitz, F. (2015). Human resources management in multinational companies in Africa: a systematic literature review. The International Journal of Human Resource Management, 26(21)2786-2809.

Infrastructure Dialogues Report. (2015). Township Economies: What is the role of infrastructure in government's strategy to revitalise township economies? 29 September 2015, 1-17.

International Finance Corporation. (2011). Strengthening Access to Finance for Women-Owned SMEs in Developing Countries, Global Partnership for Financial Inclusion and International Finance Corporation 2011, World Bank, Washington.

Jan de Kok, P. V., Wim-Verhoeven, N. T., Ton Kwaak, J. S. \& Westhof, F. (2011). Do SMEs create more and better jobs? Zoetermeer: EIM Business \& Policy Research.

Kalitanyi, V. \& Visser, K. (2010). African immigrants in South Africa: Job takers or job creators? South African Journal of Economic and Management Sciences, 13(4), 376-390.

Kanu, A. (2015). An Investigation into the Prevalence of HRM Practices in SMEs: Sierra Leone an Example. Developing Country Studies, 5(6), 11-28.

Khatri, N. (1999). Emerging issues in Strategic HRM IN Singapore. International Journal of Manpower, 20(8), 516-529.

Kim, Y. \& Gao, F. (2010). An empirical study of human resource management practices in family firms in China. The International Journal of Human Resource Management, 21(12), 2095-2119.

Laforet, S. (2013). Innovation characteristics of young and old family-owned businesses. Journal of Small Business and Enterprise Development, 20(1), 204-224.

Lee, F., Lee, T. \& Wu, W. (2010). The relationship between human resource management practices, business strategy and firm performance: evidence from steel industry in Taiwan. The International Journal of Human Resource Management, 21(9), 1351-1372.

Lekhanya, L. M. \& Mason, R. B. (2014). Selected key external factors influencing the success of rural small and medium enterprises in South Africa. Journal of Enterprising Culture, 22(3), 331-348.

Levy, B. (1993). Obstacles to Developing Indigenous Small and Medium Enterprises: An Empirical Assessment. The World Bank Economic Review, 7(1), 65-83.

Lockyer, C. \& Scholarios, D. (2005). Selecting hotel staff: why best practice does not always work. International Journal of Contemporary Hospitality Management, 16(2), 121-135.

Mahembe, E. (2011). Literature Review on Small and Medium Enterprises' Access to Credit and Support in South Africa Prepared for National Credit Regulator (NCR). Underhill Corporate Solutions (UCS), Capital Park.

Mason, C. \& Harrison, R. (2013). Business angel investment activity in the financial crisis: UK evidence and policy implications [Online]. Available: http://www.gla.ac.uk/media/media_286594_en.pdf

McMillan, J. \& Schumacher, S. (2001). Research in education: a conceptual introduction. $5^{\text {th }}$ Edition, New York, Addison-Wesley Longman.

Mosweunyane, L. D. (2013). Records management practices of hair salons in Dr. Ruth Segomotsi Mompati District Municipality. Unpublished Masters thesis. Free State: Central University of Technology, Free State. 
Mpiti, N. (2016). The influence of private and public finance on the performance of SMMEs in the Free State: a case of afro hair salons in Mangaung Metropolitan Area, Masters Thesis, Central University of Technology, Free State.

Mutezo, A. T. (2005). Obstacles in the SMME finance: An empirical perspective on Tshwane. Unpublished Masters thesis. Pretoria: University of South Africa.

Mwaka, N. (2014). Inclusive Finance: Exploring the Finance Pipeline for Women Owned SMMEs in South Africa. Final updated Report, United Nations Development Programme, Pretoria.

Nyamubarwa, W. (2016). Antecedent factors for formalizing human resource practices among family-owned small accommodation business in developing economies: Towards a conceptual framework. Interim Journal, 15(2), 1-18

Organisation for Economic Cooperation and Development (OECD). (2015). Financing SMEs and Entrepreneurs 2015: An OECD Scoreboard, OECD Publishing, Paris. http://dx.doi.org/10.1787/fin_sme_ent-2015-en

Oliphant, M. N. (2013). Government notice Department of Labour: Bargain council for hairdressing, cosmetology beauty and skincare [Online]. Available: www.gov.za/sites/www.gov.za/files/36156_rg9908_gon112.pdf[2016, June 09].

Onsongo, S. (2015). Factors Influencing the Growth of Hair Salon Enterprises in Kenya: A Survey of Hair Salon Enterprises in Kisii Town. Journal of Business and Management, 17(3), 1-15.

Rand, J. \& Torm, N. (2012). The Benefits of Formalization: Evidence from Vietnamese Manufacturing SMEs. World Development, 40(5), 983-998.

Rambe, P. \& Mpiti (2017). The influence of private and public finance, organisational and environmental variables on the performance of beauty salons in the Free State, South Africa: A theoretical perspective. International Business and Economics Research, 16(2), 101-118.

Richbell, S., Szerb, L. \& Vitai, Z. (2010). HRM in the Hungarian SME sector. Employee Relations, 32(3), 262-280.

Rwigema, H. \& Venter, R. (2004). Advanced entrepreneurship. Southern Africa: Oxford University press.

Saito, K. \& Villanueva, D. (1981). Transactions costs of credit to the small-scale sector in the Philippines. Economic Development and Cultural Change, 29(3), 631-640.

Schmidt, H. J., Mason, R., Bruwer, J. \& Aspeling, J. (2016). An exploratory study of finance accessibility for small retailers: the financial institutions' view (pp. 495-525). In Management, Business, Administration \& Legal Initiatives Conference proceedings, Premier hotel, 6 - 8 July, Richards Bay, KwaZulu Natal.

Severino, J. M. (2012). Private equity and SMEs: an instrument for growth.Investisseur \& Partenaire pour le Développement,

$22-24$ http://www.proparco.fr/webdav/site/proparco/shared/PORTAILS/Secteur_prive_developpement/ PDF/SPD12/Article_JM_Severino_SPD12_UK.pdf

Sheehan, M. (2013). Human resource management and performance: Evidence from small and medium-sized firms. International Small Business Journal, 1, 1-26.

Simpeh, K. (2011). Entrepreneurship theories and Empirical research: A Summary Review of the Literature. European Journal of Business and Management, 3(6), 1-9.

Small Enterprise Finance Agency. (2015). SEFA Annual Report 2015 http://www.sefa.org.za/Content/Docs/2015\%20sefa\%20Annual\%20Report.pdf

Small Enterprise Development Agency (n.d.). Seda Women-owned Enterprise Development Information Booklet.http://www.seda.org.za/MyBusiness/Documents/Seda\%20Women\%200wned\%20Entepri se\%20Developement\%20Information\%20Booklet.pdf

Urbano, D. \& Yordanova, D. (2008). Determinants of the adoption of HRM practices in tourism SMEs in Spain: an exploratory study. Services Business, 2(3), 167-185

Umer, M. (2012). Human resource management theory and practices in Small and Medium-Sized Enterprises (SMEs) and enterprises performance in Pakistan. Global Journal of Management and Business Research, 12(13), 29-44.

The Human Resource Development Strategy for South Africa (HRD-SA) 2010 - 2030 http://www.hrdcsa.org.za/sites/default/files/documents/Microsoft\%20Word\%20\%20HRDSA\%20strategy.doc.pdf

Timm, S. (2012). How the state and private sector can partners to boost support to SMMEs: Lessons from Chile \& Malaysia. A report for the Department of Trade and Industry (the dti) and TIPS, June 2012. 
Tiwari, P. \& Saxena, K. (2012). Human resource management practices: A comprehensive review. Pakistan Business Review, 669-705.

Urbano, D. \& Yordanova, D. (2008). Determinants of the adoption of HRM practices in tourism SMEs in Spain: an exploratory study. Service Business, 2, 167-186

Umer, M. (2012). Human resource management theory and practices in small and medium-sized enterprises (SMEs) and enterprises. Global Journal of Management and Business Research, 12(13), 29-44.

Van der Walt, F. \& Swanepoel, H. (2015). The relationship between workplace spirituality and job involvement: A South African study. African Journal of Business and Economic Research, 10(1), 95116.

Woldie, A., Leighton, P. \& Adesua, A. (2008). Factors influencing small and medium enterprises (SMEs): an exploratory study of owner/manager and firm characteristics. Banks and Bank Systems Journal, 3(3), 5-13.

Zhenxing, M. \& Zheng, G. (2008). The relationship between financial factors and firm performance: Empirical evidence from U.S. restaurant firm. Journal of Foodservice Business Research, 11(2), 139-142. 